\title{
VOLUME CHANGE BEHAVIOR OF PHOSPHOGYPSUM TREATED CLAYEY SOILS CONTAMINATED WITH INORGANIC ACIDS - A MICRO LEVEL STUDY
}

\author{
Rama Vara Prasad CHAVALI, Hari Prasad Reddy P* \\ Department of Civil Engineering, National Institute of Technology, Warangal, India
}

Received 26 December 2016; accepted 12 May 2017

\begin{abstract}
Soils exhibit undesirable volume changes when exposed to high concentrations of acids, which is manifested most frequently in the beds of foundations of industrial establishments associated with their production or use. However, control of this phenomenon has received less attention than it deserves. This paper aims to investigate the mineralogical and micro-structural changes occurred during the volume change behavior of phosphogypsum treated clayey soils contaminated with sulfuric acid and phosphoric acid solutions. Oedometer test results showed high swelling and low compressibility for acid contaminated soils than that of water. The change in microstructure towards flocculated fabric along with mineralogical transformations are responsible for the volume changes in soils. The mineralogical changes that affected the volume change behavior are discussed with FT-IR, XRD and SEM analysis. Phosphogypsum treatment was found to be effective in controlling volume changes in soils with phosphoric acid, whereas in the case of sulfuric acid found to be futile.
\end{abstract}

Keywords: acid, black cotton soil, compressibility, kaolin clay, mineralogy, microstructure, swelling.

\section{Notations}

BW - Black cotton soil inundated with water;

BS - Black cotton soil inundated with sulfuric acid;

BP - Black cotton soil inundated with phosphoric acid;

BGS - Black cotton soil treated with phosphogypsum and inundated with sulfuric acid;

BGP - Black cotton soil treated with phosphogypsum and inundated with phosphoric acid;

KW - Kaolin clay inundated with water;

KS - Kaolin clay inundated with sulfuric acid;

KP - Kaolin clay inundated with phosphoric acid;

KGS - Kaolin clay treated with phosphogypsum and inundated with sulfuric acid;

KGP - Kaolin clay treated with phosphogypsum and inundated with phosphoric acid;

FT-IR - Fourier transform infrared;

XRD - X-ray diffraction;

SEM - Scanning electron microscopy.

\section{Introduction}

Industrial chemicals often leak into soil or rocks resulting in contamination (Assa'ad 1998; Al-Omari et al. 2007). It has long been recognized that soil contamination has a significant effect on the volume change behavior of soil, which in turn can have direct bearing on their geotechnical properties and can affect the stability of structures built on them (Lukas, Gnaedinger 1972; Sokolovich, Troitskii 1976; Sibley, Vadgama 1986; Chunikhin et al. 1988; Rao, S. M., Rao, K. S. S. 1994; Sivapullaiah et al. 2004). Soil contamination problems pose new challenges to the current geotechnical engineering practice as it involves complex chemical reactions between soil and contaminant. It requires a better understanding of compositional characteristics of soils and their relation to the long-term physical and chemical properties that control soil behavior under changed and extreme environmental conditions (Mitchell 1993). Failures of structures and tilting of acid storage tanks in fertilizer industry due to accidental spillage or leakages of phosphoric acid with the subsequent heaving of foundation soils have been investigated in India (Sridharan et al. 1981; Rao, Reddy 1997) and other countries (Grant et al. 1974; Joshi et al. 1994; Assa’ad 1998; Al-Omari et al. 2007). It has been reported that sulfuric acid contaminated soils also reveal high swelling which resulted in distress to the structures built on them (Vronskii et al. 1978; Stephenson et al. 1989; Shekhtman et al.

*Corresponding author. E-mail: ponnapuhari@gmail.com 
1995). Studies on acid contaminated soils indicated that dissolution of aluminosilicate of clay mineral with subsequent mineral formations leads to volume changes in soils (Sokolovich 1995; Mal'tsev 1998; Sivapullaiah et al. 2009). Several researchers have investigated the influence of acid treatment on natural clay minerals (Grim 1953; Mitchell 1993; Madejova et al. 1998; Gates et al. 2002; Komadel 2003, 2016; Tyagi et al. 2006; Onal 2007; Steudel et al. 2009; Panda et al. 2010; Zhang et al. 2012) and found that mineral alterations depend on nature of acid, concentration of acid, temperature and duration of interaction.

Izbash et al. (1989) reported that dissolution of carbonates in soils with subsequent formation of crystallohydrated phosphoric acid salts with the liberation of $\mathrm{CO}_{2}$ in the acidic environment lead to heaving of carbonate soils and proposed to use silicate-injection method to counter the swelling problem. Isaev et al. (1995) suggested washing soils with water to reduce the mineralization of the acid-containing rocks and to protect the foundation soils from acids. AlOmari et al. (2007) recommended chemical grouting using a two-shot injection of sodium silicate and calcium chloride to overcome the cyclic heave and settlement problem due to contamination of limestone foundation with acids. Subsequent to this, studies by Al-Khailany et al. (2008) found that use of calcium chloride with sodium silicate did not show any additional advantage to counter the heave problem and proved that sodium silicate grouting is the best alternative to overcome the problem in acid contaminated limestone. However, these grouting techniques suggested by the researchers are not suited for clayey soils.

On the other hand, a large quantity of phosphogypsum, which is a by-product of the fertilizer industry, is being generated leading to disposal, environmental and health problems. As indicative of its name, "phospho" refers to its industrial origin, and "gypsum" indicates its predominant composition (Ghafoori, Chang 1993). In the recent times, utilization of phosphogypsum as a stabilizer to improve the engineering behavior of expansive soils has been increasingly reported in the literature (Degirmenci et al. 2007; Shen et al. 2007; James, Pandian 2014; Kumar et al. 2014, 2015; De Rezende et al. 2016). Utilization of phosphogypsum with cement and fly ash for stabilization can significantly improve the unconfined compressive strength of soil (Degirmenci et al. 2007). Strength and performances of the road base material stabilized with limephosphogypsum-fly ash binder was much superior than those of the lime-fly ash road base material binder (Shen et al. 2007). James and Pandian (2014) found that the addition of phosphogypsum to lime led to the improvement of both the early and late strength of stabilized soil. An increase in the percentage swell of the bentonite-lime mix with the addition of the phosphogypsum was attributed to the formations of ettringite crystals on the surface of the bentonite plates, within a colloidal calcium silicate and aluminate hydrates (Kumar et al. 2014). In continuation, Kumar et al. (2015) reported considerable improvement in the unconfined compressive strength and bearing ratio of the bentonite treated with lime-phosphogypsum.
De Rezende et al. (2016) reported that hemi-hydrate phosphogypsum cement and lime mixes reduces the swelling of tropical soil and provides better mechanical behavior compared to the use of dihydrate phosphogypsum. Nevertheless, the efficiency of phosphogypsum in overcoming acid induced swelling has not yet been established. Hence, in this present study, an attempt has been made to find out the effectiveness of phosphogypsum to control acid induced heave in soils.

\section{Materials and methods}

\subsection{Clays and solutions used}

Naturally occurring black cotton soil and commercially available kaolin clay were examined in this study. The expansive black cotton soil was collected by open excavation, from a depth of one meter from natural ground level at National Institute of Technology, Warangal (Latitude: $17^{\circ} 98^{\prime} \mathrm{N}$ \& Longitude: $79^{\circ} 53^{\prime} \mathrm{E}$ ), India. The kaolin clay was purchased from Godavari Mines and Minerals, Visakhapatnam (Latitude: $17^{\circ} 72^{\prime} \mathrm{N} \&$ Longitude: $82^{\circ} 73^{\prime} \mathrm{E}$ ), India. The XRD analysis indicated that the black cotton soil consists predominantly of a montmorillonite mineral while the kaolin clay was dominated by kaolinite mineral. All the clays are oven dried and sieved through no. 40 $(425 \mu)$ sieve prior to usage. The physical properties and chemical composition of soils are presented in Table 1 and Table 2. The chemical composition of soils was evaluated with the help of X-ray fluorescence (XRF) spectroscopy technique. Phillips PW 2404 X-ray fluorescence spectrometer was used for XRF analysis. Grain size distribution curves of soils are shown in Figure 1. The concentration of sulfuric acid and phosphoric acid used for different industrial purposes ranges from 12-40 $\mathrm{N}$ and when these acid solutions leak into the subsoil and are diluted, the concentration may range within 1-4 N (Sivapullaiah et al. 2009). Further, Sheng and $\mathrm{Mu}$ (1998) reported the concentration of waste sulfuric acid released from aluminium finishing industry to be about $4.05 \mathrm{~N}$. Thus, distilled water, $4 \mathrm{~N}$ concentrations of commercially available sulfuric acid (Assay 98\%) and phosphoric acid (Assay 88\%) solutions were used as pore fluids to mimic those conditions.

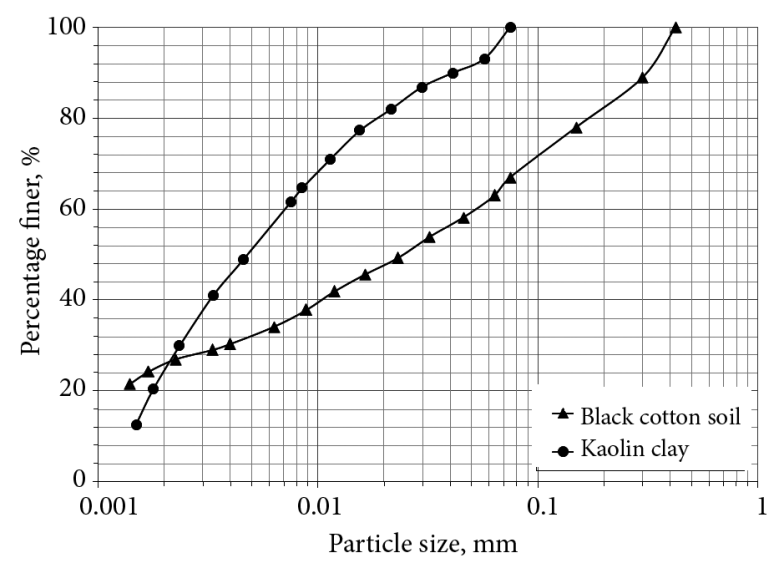

Figure 1. Particle size distribution curve for soils 
Table 1. Physical properties of soils

\begin{tabular}{|c|c|c|c|}
\hline Property & $\begin{array}{l}\text { Black cotton } \\
\text { soil }\end{array}$ & Kaolin clay & Standards \\
\hline $\begin{array}{l}\text { Specific } \\
\text { gravity }\end{array}$ & 2.63 & 2.65 & IS 2720 Part 3 \\
\hline $\begin{array}{l}\text { Liquid Limit } \\
(\%)\end{array}$ & 60 & 52 & \multirow{2}{*}{ IS 2720 Part 5} \\
\hline $\begin{array}{l}\text { Plastic Limit } \\
(\%)\end{array}$ & 18 & 27 & \\
\hline $\begin{array}{l}\text { Plasticity } \\
\text { Index (\%) }\end{array}$ & 42 & 25 & - \\
\hline $\begin{array}{l}\text { Clay, }<2 \mu \mathrm{m} \\
(\%)\end{array}$ & 26 & 21 & \multirow{3}{*}{ IS 2720 Part } \\
\hline $\begin{array}{l}\text { Silt, } 75 \text { to } 2 \\
\mu \mathrm{m}(\%)\end{array}$ & 41 & 79 & \\
\hline $\begin{array}{l}\text { Fine sand, } \\
425 \text { to } 75 \mu \mathrm{m} \\
(\%)\end{array}$ & 33 & - & \\
\hline $\begin{array}{l}\text { Soil } \\
\text { classification }\end{array}$ & $\mathrm{CH}$ & CL & IS 1498 \\
\hline $\begin{array}{l}\text { Cation } \\
\text { exchange } \\
\text { capacity } \\
\text { (meq/100g) }\end{array}$ & 37.5 & 5.62 & $\begin{array}{c}\text { Cokca and } \\
\text { Birand (1993) }\end{array}$ \\
\hline $\begin{array}{l}\text { Maximum } \\
\text { dry density } \\
\left(\mathrm{kN} / \mathrm{m}^{3}\right)\end{array}$ & 16.5 & 14.8 & \multirow{2}{*}{ IS 2720 Part 7} \\
\hline $\begin{array}{l}\text { Optimum } \\
\text { moisture } \\
\text { content (\%) }\end{array}$ & 16.6 & 27.3 & \\
\hline
\end{tabular}

\subsection{Phosphogypsum}

Phosphogypsum used in the present study was collected from Coromandel International Limited fertilizer plant, Visakhapatnam (Latitude: 17 72'N \& Longitude: 82 73'E), India. Phosphogypsum production in India is 11 Million tonnes per annum (СРCB 2012). According to James and Pandian (2014), phosphogypsum contains $32 \%$ calcium oxide $(\mathrm{CaO}), 43.6 \%$ sulfur trioxide $\left(\mathrm{SO}_{3}\right)$ and $18 \% \mathrm{com}$ bined water $\left(\mathrm{H}_{2} \mathrm{O}\right)$. The percentage of phosphogypsum used in the current study was limited to $10 \%$.

\subsection{Oedometer test}

The conventional odeometer tests were conducted according to IS 2720-15 (1986) to investigate the effects of acid contamination on the swelling and compressibility of phosphogypsum treated soils. Special teflon oedometer rings were made, which were entirely non-reactive to acid. Soils were mixed thoroughly with distilled water at optimum moisture content corresponding to maximum
Table 3. FT-IR band assignments for black cotton soil

\begin{tabular}{|c|l|}
\hline Position $\left(\mathrm{cm}^{-1}\right)$ & \multicolumn{1}{|c|}{ Assignments } \\
\hline 3628 & $-\mathrm{OH}$ stretching \\
\hline 3429 & -OH stretching, hydration \\
\hline 1638 & -OH bending, hydration \\
\hline 1429 & $\mathrm{CO}_{3}$ stretching of calcite \\
\hline 1028 & Si-O stretching, in-plane \\
\hline 915 & AlAlOH bending \\
\hline 796 & Si-O stretching of quartz and silica \\
\hline 778 & Si-O stretching of quartz \\
\hline 694 & Si-O \\
\hline 534 & Al-O-Si bending \\
\hline 467 & Si-O-Si bending \\
\hline
\end{tabular}

dry density and were placed in a sealed plastic bag. The plastic bags were placed in desiccator for 24 hours, to attain uniform moisture content. Silicon grease was applied to the inner surface of the oedometer ring to reduce the friction during compaction. Soil specimens were then compacted in the oedometer cell $(6 \mathrm{~cm}$ in diameter and 2 $\mathrm{cm}$ in height) to their maximum dry density to a height of $1.4 \mathrm{~cm}$. The volume of the pore fluid used for all soil specimens was about $500 \mathrm{ml}$ and testing was carried out at room temperature of $27^{\circ} \mathrm{C}$. The prepared soil specimens were inundated with distilled water, $1 \mathrm{~N}$ and $4 \mathrm{~N}$ concentrations of sulfuric acid and phosphoric acid solutions as pore fluid and allowed to swell at a seating load of $5 \mathrm{kPa}$ to reach equilibrium. The loads were subsequently increased to $10,20, \ldots . ., 640 \mathrm{kPa}$ (with a standard load increment ratio of unity from $5 \mathrm{kPa}$ onwards). In a significant number of cases, the experiments were repeated atleast twice to check the reproducibility of results. The changes in thickness of the specimen were recorded against time to obtain the swelling at the seating load, and the compression at the end of each load stage. The compression index " $C_{c}$ " was computed as given in Eq. (1):

$$
C_{c}=\left(e_{0}-e\right) /\left(\log \left(p / p_{0}\right)\right),
$$

where " $C_{c}$ " is equal to the slope of the consolidation curve plotted on a logarithmic scale of pressure " $p$ ", in the linear range. " $p_{0}$ " and " $p$ " are pressure values corresponding to initial void ratio " $e_{0}$ " and final void ratio " $e$ ", respectively.

Representative soil samples were collected at the completion of the oedometer tests and were analyzed using FT-IR spectroscopy, X-ray diffraction analysis and scanning electron microscopy tests to identify the chemicomineralogical and morphological changes that might have occurred due to contamination.

Table 2. Chemical composition of soils

\begin{tabular}{|l|c|c|c|c|c|c|c|c|c|c|c|}
\hline Soil & $\mathrm{SiO}_{2}$ & $\mathrm{Al}_{2} \mathrm{O}_{3}$ & $\mathrm{Fe}_{2} \mathrm{O}_{3}$ & $\mathrm{MgO}$ & $\mathrm{CaO}$ & $\mathrm{Na}_{2} \mathrm{O}$ & $\mathrm{K}_{2} \mathrm{O}$ & $\mathrm{TiO}_{2}$ & $\mathrm{P}_{2} \mathrm{O}_{5}$ & $\mathrm{MnO}$ & $\mathrm{SO}_{3}$ \\
\hline Black cotton soil & 43.6 & 22.8 & 14.7 & 7.3 & 7.5 & 0.255 & 0.63 & 1.71 & 0.28 & 0.47 & 0.14 \\
\hline Kaolin clay & 34.5 & 49.0 & 6.5 & 2.3 & 5.3 & 0.034 & 0.17 & 1.22 & 0.15 & 0.17 & 0.11 \\
\hline
\end{tabular}




\subsection{Fourier transform infrared spectroscopy}

FT-IR study was performed using a Perkin Elmer 100S equipped with a standard DTGS detector. Infrared spectra for each sample were recorded in the spectral range of $400-4000 \mathrm{~cm}^{-1}$ at a resolution of $4 \mathrm{~cm}^{-1}$ with $\mathrm{KBr}$ pellets technique. Around $2 \mathrm{mg}$ of dried representative soil sample collected at the end of oedometer test was mixed with $\mathrm{KBr}$ powder (around 1:100) to prepare $\mathrm{KBr}$ pellets and were pressed with disc technique.

\subsection{X-ray diffraction test}

Mineralogical composition of soils was determined using PANanalytical X-ray diffractometer. At the end of each swell and compressibility test representative soil samples were collected. The representative samples collected at the end of oedometer tests were oven dried for 24 hours. The dried samples were scanned between two theta values of $6^{\circ}$ to $70^{\circ}$ with a step size of $0.02^{\circ}$. The X-Ray Tube was operated at $60 \mathrm{kV}$ and $55 \mathrm{~mA}$ using an X'Celerator ultra fast detector. Qualitative identification of minerals was conducted using X'pert high score plus software based on database provided by Joint Committee of Powder Diffraction Data Service (PCPDFWIN 1999).

\subsection{Scanning electron microscopy}

Morphological studies on soil samples were carried out using TESCAN VEGA 3LMU microscope with conventional tungsten heated cathode having live stereoscopic imaging using $3 \mathrm{D}$ beam technology. The samples were coated with gold using a sputter coater prior to scanning.

\section{Results and discussions}

\subsection{Structural modifications of black cotton soil}

The functional groups of soil minerals can be determined by measuring the absorption bands at characteristic wavelengths of bonds with Fourier transform infrared spectroscopy. The FT-IR spectrums of phosphogypsum treated black cotton soil contaminated with acid solutions are shown in Figure 2. The corresponding positions and band assignments are presented in Table 3. In addition to the common montmorillonite band assignments, diagnostic bands of quartz and calcite, present as an impurity in this sample are observed at 796, 778, and $1429 \mathrm{~cm}^{-1}$. The presence of quartz and calcite are confirmed by XRD analysis. The bands at $3628 \mathrm{~cm}^{-1}$ was attributed to the $\mathrm{OH}$ stretching of inner hydroxyl groups. The bands at $1028 \mathrm{~cm}^{-1}$ and $694 \mathrm{~cm}^{-1}$ corresponded to the in-plane $\mathrm{Si}-\mathrm{O}$ stretching and $\mathrm{Si}-\mathrm{O}$. The other bands such as the Al$\mathrm{O}-\mathrm{Si}$ deformation at $534 \mathrm{~cm}^{-1}$ and Si-O-Si deformation at $467 \mathrm{~cm}^{-1}$ confirmed the presence of montmorillonite mineral. The remaining bands were assigned to water vibrations. Band at $3429 \mathrm{~cm}^{-1}$ was a stretching vibration, whereas the $1638 \mathrm{~cm}^{-1}$ band was a deformation vibration of water. The FT-IR spectrum of uncontaminated black

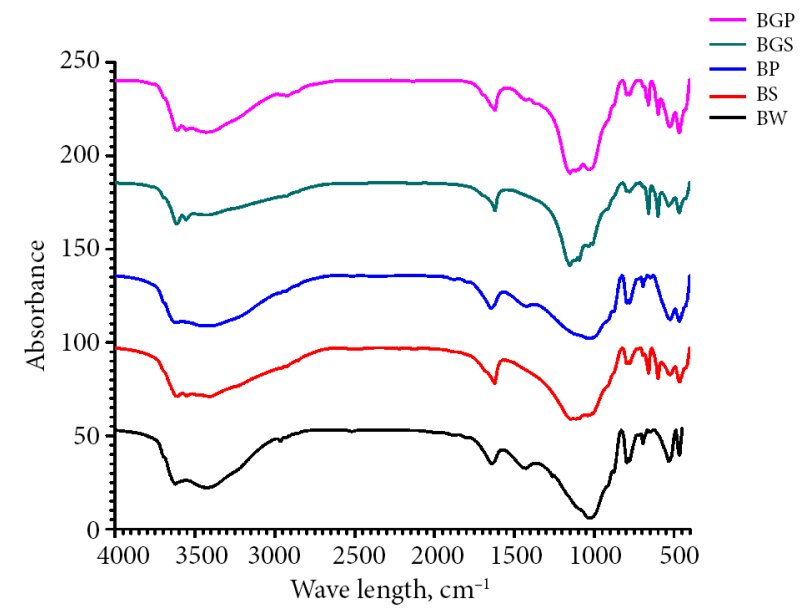

Figure 2. FT-IR patterns of black cotton soil

cotton soil shows band at $3628 \mathrm{~cm}^{-1}$ in $-\mathrm{OH}$ stretching region is due to a hydroxyl group bonded with octahedral $\left(\mathrm{Al}^{+}\right)$cations (Vicente-Rodriguez et al. 1996). When the soil was contaminated with acids the peak pattern completely disappeared, which indicates the leaching of octahedral cations. It can be seen from the FTIR spectrum that (i) the shape of Si-O stretching band at $1028 \mathrm{~cm}^{-1}$ and (ii) shift in Si-O stretchings at $694 \mathrm{~cm}^{-1}$ towards lower intensity, indicate the changes in the Si environment after acid contamination. The peak at $915 \mathrm{~cm}^{-1}$ owing to the vibrations of inner $\mathrm{OH}$ groups coordinated to AlAl pairs was found to be disappeared in acid contaminated soils (Madejova, Komadel 2001). The Al-O-Si deformation at $534 \mathrm{~cm}^{-1}$ shifted towards lower frequency and its intensity decreased with increasing concentration of both acids, which shows the partial decrease of octahedral cations due to acid contamination. No change was observed in $\mathrm{Si}-\mathrm{O}-\mathrm{Si}$ deformation due to acid attack. The disappeared band at $1429 \mathrm{~cm}^{-1}$ suggests the dissolution of calcite. The peaks at 3429 and $1638 \mathrm{~cm}^{-1}$ for water of hydration show significant decrease with increasing acid concentration. This is due to the removal of octahedral cations causing the loss of water and hydroxyl groups coordinated to them. The observed FT-IR results meet the conclusions reported by Tyagi et al. (2006), who stated the dissolution of octahedral cations from the aluminosilicate nucleus of montmorillonite clay due to acid treatment. The above mentioned structural modifications were clearly attributed to the dissolution of clay minerals. Further, in phosphogypsum treated soils, even after acid contamination, there was only a slight variation in the peak pattern corresponding to band at $3628 \mathrm{~cm}^{-1}$. The bands at 3429 and $1638 \mathrm{~cm}^{-1}$ were not much affected after phosphogypsum treatment. The band at $1429 \mathrm{~cm}^{-1}$ corresponding to calcite disappeared. The alterations owing to Si-O stretchings were also trivial after phosphogypsum treatment. Though changes were noticed in peak related to octahedral groups at $915 \mathrm{~cm}^{-1}$, it can be seen that the phosphogypsum treatment resisted the acid attack without significant mineral dissolution. 


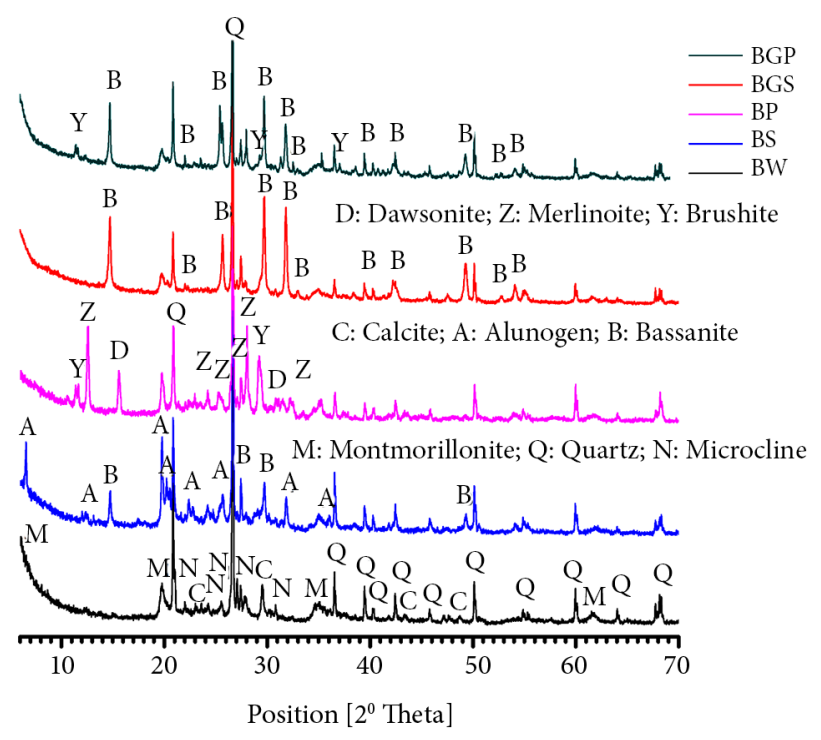

Figure 3. XRD patterns of black cotton soil

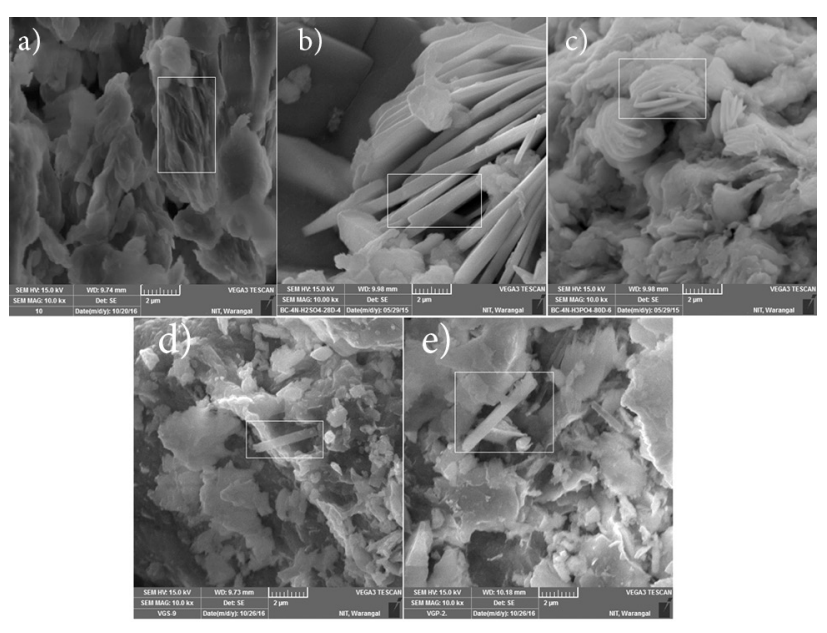

Figure 4. SEM images black cotton soil (a) BW (b) BS (c) BP (d) BGS (e) BGP

\subsection{Mineralogical and microstructural modifications of black cotton soil}

The mineral alterations that occurred in the phosphogypsum treated soil due to acid contamination were assessed using XRD technique. Figure 3 depicts the XRD patterns of phosphogypsum treated black cotton soil contaminated with acids. It is observed that the black cotton soil predominant with montmorillonite, quartz and microcline revealed new peaks pertaining to alunogen and bassanite due to contamination with sulfuric acid. The d-spacings and chemical formula of minerals diagnosed in soil were presented in Table 4. Formation of alunogen mineral in sulfuric acid contaminated soil was reported by Sivapullaiah (2015). Similarly, phosphoric acid contamination resulted in formation of brushite, merlinoite and dawsonite minerals. Merlinoite is a zeolite mineral. The formations of zeolite generally happen in alkaline environment (Jha, Sivapullaiah 2014), whereas some zeolites such as mordenite and analcime were also found in acidic soils (Ming, Boettinger 2001). The transformation of merlinoite from microcline mineral was reported by Pakhomova et al. (2014). Acid contamination results in substitution of exchangeable interlayer cations by hydrogen ions releasing exchangeable cations which combined with sulphate and phosphate anions present in the solution (Sivapullaiah et al. 2009; Gratchev, Towhata 2011). This reaction leads to formation of aluminum sulphate hydrate (alunogen), calcium sulphate hydrate (bassanite) and calcium phosphate hydrate (brushite) minerals. Heave in soils due to formation of brushite mineral in presence of phosphoric acid was reported in literature (Joshi et al. 1994). Phosphogypsum treated soil shows peaks pertaining to bassanite and brushite minerals along with quartz and montmorillonite. It can be seen that the montmorillonite mineral dissolution and neogenic formations have been restricted in both acids. The bassanite mineral was formed due to the precipitation of calcium sulphate hydrate, present in phosphogypsum, around the clay particles. Further, the formation of new minerals can be supported by SEM studies (Figure 4). The natural black cotton soil exhibited dispersed undulating

Table 4. d-spacings and chemical formula of minerals found in black cotton soil

\begin{tabular}{|c|l|l|l|}
\hline Notation & \multicolumn{1}{|c|}{ Mineral } & \multicolumn{1}{|c|}{ Major diagnosed d-spacings } & \multicolumn{1}{c|}{ Chemical formula } \\
\hline M & Montmorillonite & $12.90 \mathrm{~A}(001), 4.50 \mathrm{~A}(002), 2.59 \mathrm{~A}(003)$ & $\mathrm{Ca}_{0.2}(\mathrm{Al}, \mathrm{Mg})_{2} \mathrm{Si}_{4} \mathrm{O}_{10}\left(\mathrm{OH}_{2} \cdot 4 \mathrm{H}_{2} \mathrm{O}\right.$ \\
\hline $\mathrm{Q}$ & Quartz & $3.34 \mathrm{~A}(001), 4.25 \mathrm{~A}(002), 1.81 \mathrm{~A}(003)$ & $\mathrm{SiO}_{2}$ \\
\hline $\mathrm{N}$ & Microcline & $3.26 \mathrm{~A}(001), 4.03 \mathrm{~A}(003), 3.50 \mathrm{~A}(004)$ & $\mathrm{KAlSi}_{3} \mathrm{O}_{8}$ \\
\hline C & Calcite & $3.03 \mathrm{~A}(001), 1.87 \mathrm{~A}(002), 3.87 \mathrm{~A}(003)$ & $\mathrm{CaCO}_{3}$ \\
\hline A & Alunogen & $4.48 \mathrm{~A}(001), 13.30 \mathrm{~A}(002), 4.39 \mathrm{~A}(003)$ & $\mathrm{Al}_{2}\left(\mathrm{SO}_{4}\right)_{3} \cdot 17 \mathrm{H}_{2} \mathrm{O}$ \\
\hline B & Bassanite & $3.00 \mathrm{~A}(001), 6.00 \mathrm{~A}(003), 1.85 \mathrm{~A}(004)$ & $\mathrm{CaSO}_{4} \cdot 0.5 \mathrm{H}_{2} \mathrm{O}$ \\
\hline $\mathrm{D}$ & Dawsonite & $5.70 \mathrm{~A}(001)$ & $\mathrm{NaAl}_{\left(\mathrm{CO}_{3}\right)(\mathrm{OH})_{2}}$ \\
\hline $\mathrm{Z}$ & Merlinoite & $3.18 \mathrm{~A}(001), 7.08 \mathrm{~A}(002), 3.24 \mathrm{~A}(003)$ & $\mathrm{K}_{5} \mathrm{Ca}_{2}\left(\mathrm{Al}_{9} \mathrm{Si}_{23} \mathrm{O}_{64}\right) \cdot 24 \mathrm{H}_{2} \mathrm{O}$ \\
\hline $\mathrm{Y}$ & Brushite & $7.62(001), 3.06 \mathrm{~A}(003)$ & $\mathrm{CaHPO}_{4} 2 \mathrm{H}_{2} \mathrm{O}$ \\
\hline
\end{tabular}


filmy particle microstructure similar to that of montmorillonite (Latifi et al. 2016). The needle-like mineral formation can be evidenced from sulfuric acid contaminated soil, which refers to alunogen mineral formation. Formation of flower-like brushite structures were seen in soil contaminated with phosphoric acid (Brundavanam et al. 2014). Phosphogypsum treated soils contaminated with acids show lath-like crystals refer to bassanite mineral formations (Azam 2003). These changes in microstructure clearly indicate the effect of acid contamination and phosphogypsum treatment on clay mineral behavior.

\subsection{Volume change behavior of black cotton soil}

One dimensional swell tests on black cotton soil with deionised water and different concentrations of acid solutions as pore fluid are presented in Figure 5. The figure depicts that the soil inundated with water exhibited an equilibrium swelling of about $6 \%$. The observed swelling is due to the presence of montmorillonite. Further, the soil with sulfuric acid and phosphoric acid exhibited an equilibrium swelling of about $25 \%$ and $14 \%$, respectively. The highly concentrated acids replace the commonly found exchangeable cations from the diffuse double layer by hydrogen ion. In black cotton soil, the dominant cation $\mathrm{Ca}^{++}$gets replaced by $\mathrm{H}^{+}$ion. Thus, $\mathrm{H}^{+}$ion being monovalent ion, the swelling due to double layer is more, when compared to the divalent $\mathrm{Ca}^{++}$ion (Olphen 1991). Low amount of swelling exhibited by soil with phosphoric acid than sulfuric acid may be attributed to the less tendency of the phosphoric acid to release the $\mathrm{H}^{+}$ions. In addition, Olphen (1991), Mitchell (1993) noted that at extremely high concentrations of acid ( $\mathrm{pH} 1)$, significant changes in the mineral structure may occur (for example, dissolution of $A l^{3+}$ ), a process that would likely affect volume change behavior of soil. Thus, the black cotton soil behavior can be explained by mineralogical changes rather than double layer theory. The decrease in compressibility at high external loads is due to formation of flocculant fabric along with mineral transformations (Figure 6). The XRD results clearly support the above statement. It can be seen from XRD analysis results, (i) mineral dissolution along with formation of alunogen and bassanite in sulfuric acid (ii) formation of merlinoite, dawsonite and brushite in phosphoric acid, that they can explain an increase in swelling and a decrease in compressibility of soil. The mineral dissolution and mineral formations were further supported by FT-IR spectroscopy and SEM results. Furthermore, it is seen from Figure 5 that phosphogypsum treated soil exhibited an equilibrium swelling of about $20 \%$ and $5 \%$ with sulfuric acid and phosphoric acid, respectively. The void ratio - pressure plots of phosphogypsum treated soil inundated with acids exhibited higher deformation than that of untreated soil (Table 5). As stated earlier (in XRD analysis), the decrease in montmorillonite mineral dissolution and neogenic formations has resulted in a decrease in swelling and an increase in deformation of phosphogypsum treated black cotton soil in both acids.

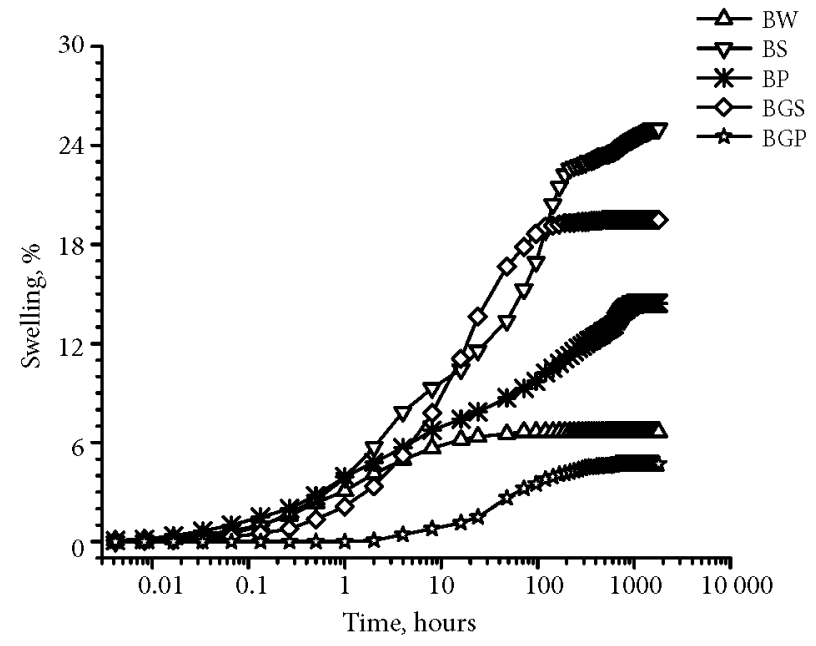

Figure 5. Time- swelling curves of black cotton soil

Table 5. Compression index of black cotton soil

\begin{tabular}{|c|c|}
\hline Soil & Compression index, $\mathrm{C}_{\mathrm{c}}$ \\
\hline BW & 0.15 \\
\hline BS & 0.11 \\
\hline BP & 0.03 \\
\hline BGS & 0.20 \\
\hline BGP & 0.09 \\
\hline
\end{tabular}

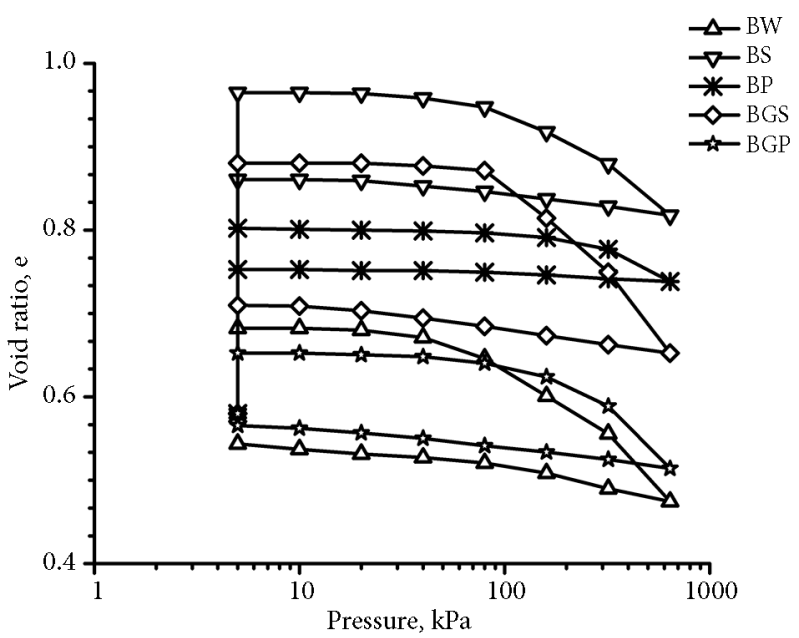

Figure 6. Compressibility behavior of black cotton soil

\subsection{Structural modifications of kaolin clay}

Figure 7 shows the FT-IR spectrums of kaolin clay and its phosphogypsum treated counterparts upon contamination with acid solutions. The corresponding positions and band assignments are presented in Table 6. The characteristic bands of FT-IR spectrums for kaolin clay were as follows: The bands at 3620,3653 and $3695 \mathrm{~cm}^{-1}$ were attributed to the $\mathrm{OH}$ stretching of inner hydroxyl groups bonded with octahedral cations. Band at $3480 \mathrm{~cm}^{-1}$ was a stretching vibration, whereas the $1634 \mathrm{~cm}^{-1}$ band was 
a deformation vibration of physisorbed water. Band at $1421 \mathrm{~cm}^{-1}$ was attributed to the $\mathrm{CO}_{3}$ stretching of calcite with additional adsorption bands at 1031, $1008 \mathrm{~cm}^{-1}$ and $695 \mathrm{~cm}^{-1}$ corresponding to the in-plane and perpendicular $\mathrm{Si}-\mathrm{O}$ stretchings. Similarly, $1104 \mathrm{~cm}^{-1}$ represents the outof-plane stretchings of silica. The band at $797 \mathrm{~cm}^{-1}$ suggests the stretchings of silica. The other bands such as the $\mathrm{Al}-\mathrm{O}-\mathrm{Si}$ deformation at $538 \mathrm{~cm}^{-1}$ and $\mathrm{Si}$-O-Si deformation at $470 \mathrm{~cm}^{-1}$ confirmed the presence of kaolinite mineral. When the soil was contaminated by acids except the bands at $1421,538,470 \mathrm{~cm}^{-1}$ very nominal changes in shapes were observed at other bands. Similar to black cotton soil, the band at $1421 \mathrm{~cm}^{-1}$ were completely disappeared which confirms the dissolution of calcite. Major changes were noticed in shapes of other bands such as the Al-OSi deformation at $538 \mathrm{~cm}^{-1}$ and Si-O-Si deformation at $470 \mathrm{~cm}^{-1}$. These structural modifications clearly indicate the dissolution of octahedral cations of clay minerals. Further, FT-IR spectrums of phosphogypsum treated kaolin clay contaminated with acids also exhibited similar band patterns much like untreated clay. Even the band shapes were much affected as compared to that of untreated clay.

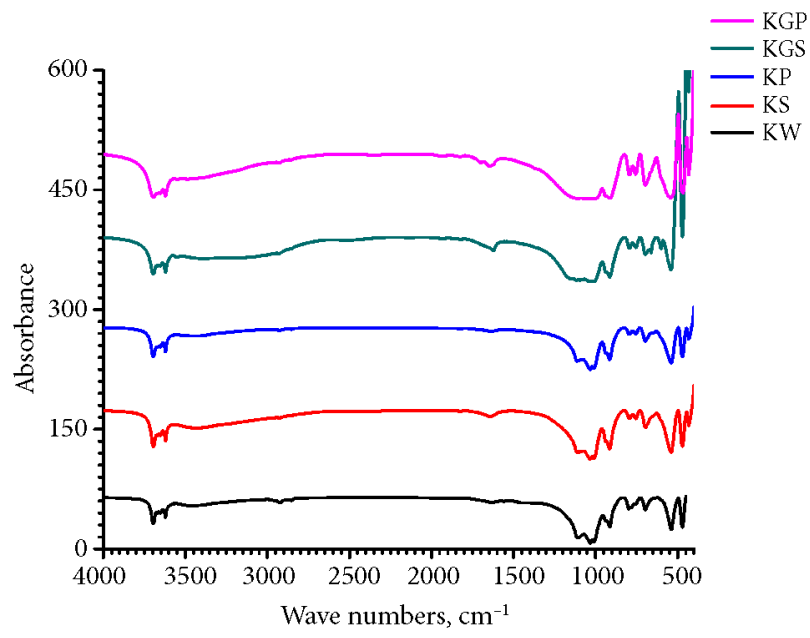

Figure 7. FT-IR patterns of kaolin clay

Table 6. FT-IR band assignments for kaolin clay

\begin{tabular}{|l|l|}
\hline \multicolumn{1}{|c|}{ Position $\left(\mathrm{cm}^{-1}\right)$} & \multicolumn{1}{c|}{ Assignments } \\
\hline $3695,3653,3620$ & -OH stretching \\
\hline 3480 & -OH stretching, hydration \\
\hline 1634 & -OH bending, hydration \\
\hline 1421 & $\mathrm{CO}_{3}$ stretching of calcite \\
\hline 1104 & Si-O stretching, out-of-plane \\
\hline 1031,1008 & Si-O stretching, in-plane \\
\hline 913 & AlAlOH bending \\
\hline 797 & Si-O stretching \\
\hline 695 & Si-O stretching, Si-O-Al stretching \\
\hline 538 & Al-O-Si bending \\
\hline 470 & Si-O stretching \\
\hline
\end{tabular}

Though changes were noticed in band shapes at 538 and $470 \mathrm{~cm}^{-1}$, it can be seen that the phosphogypsum treatment resisted volume changes due to acid contamination.

\subsection{Mineralogical and microstructural modifications of kaolin clay}

XRD patterns of natural and treated kaolin clay contaminated with acid solutions are presented in Figure 8. It can be seen from the figure that the kaolin clay is predominated with kaolinite mineral peaks along with a peak pertaining to calcite and ankerite. Dissolution of peaks pertaining to calcite and ankerite can be seen from acid contaminated kaolin clays. The d-spacings and chemical formula of minerals diagnosed in kaolin clay were presented in Table 7. The kaolin clay contaminated with sulfuric acid exhibited new peaks pertaining to bassanite and anhydrite. The adsorption of sulphate resulted in formation of calcium sulphate minerals in kaolin clay with sulfuric acid. Phosphoric acid contamination leads to formation of sarcopside mineral. The replacement of hydroxyls in kaolinite mineral structure with phosphate anion in the phosphoric acid solution resulted in the formation of sarcopside mineral. Sarcopside is an iron phosphate mineral. The presence of hydrous oxides of $\mathrm{Fe}$ and $\mathrm{Al}$ in kaolinitic soils may result in a net positive charge and the dominance of anion exchange in these soils at acidic environment (Ross 1989). In the presence of phosphoric acid, slow diffusion of phosphate ion into micropores takes place which results in slow weathering of surface in the presence of phosphate along with formation of metal phosphates $(\mathrm{Li}$, Stanforth 2000). Formation of iron phosphate hydrate in phosphoric acid treated lateritic clay was reported by Eisazadeh et al. (2011). Phosphogypsum treated kaolin clay shows peaks pertaining to bassanite and brushite minerals along with kaolinite. The structural variations and mineral alterations are well supported by SEM images. The kaolin clay exhibited large particles that appeared to have

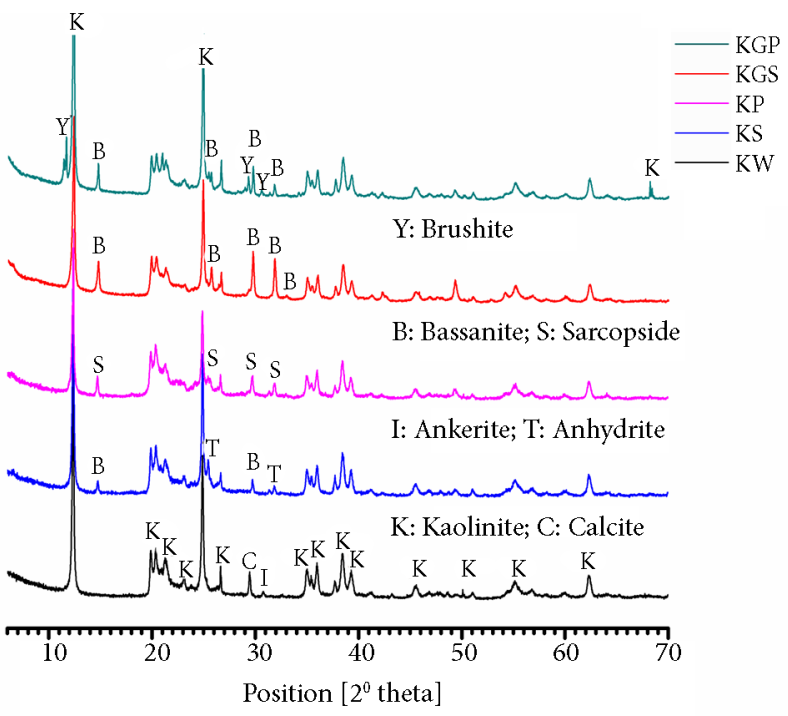

Figure 8. XRD patterns of kaolin clay 
Table 7. d-spacings and chemical formula of minerals found in kaolin clay

\begin{tabular}{|c|l|l|l|}
\hline Notation & \multicolumn{1}{|c|}{ Mineral } & \multicolumn{1}{|c|}{ Major diagnosed d-spacings } & \multicolumn{1}{c|}{ Chemical formula } \\
\hline K & Kaolinite & 7.15A $(001), 3.58 \mathrm{~A}(002), 2.34 \mathrm{~A}(003)$ & $\mathrm{Al}_{2} \mathrm{Si}_{2} \mathrm{O}_{5}(\mathrm{OH})_{4}$ \\
\hline C & Calcite & $3.03 \mathrm{~A}(001)$ & $\mathrm{CaCO}_{3}$ \\
\hline I & Ankerite & $2.90 \mathrm{~A}(001)$ & $\mathrm{Ca}(\mathrm{Fe}, \mathrm{Mg})\left(\mathrm{CO}_{3}\right)_{2}$ \\
\hline T & Anhydrite & $3.49 \mathrm{~A}(001), 2.85 \mathrm{~A}(002)$ & $\mathrm{CaSO}_{4}$ \\
\hline B & Bassanite & $3.00 \mathrm{~A}(001), 6.00 \mathrm{~A}(003), 1.85 \mathrm{~A}(004)$ & $\mathrm{CaSO}_{4} \cdot 0.5 \mathrm{H}_{2} \mathrm{O}$ \\
\hline S & Sarcopside & $\begin{array}{l}6.02 \mathrm{~A}(001), 3.52 \mathrm{~A}(002), 3.01 \mathrm{~A}(003), 2.81 \mathrm{~A} \\
(004)\end{array}$ & $\mathrm{Fe}_{3}\left(\mathrm{PO}_{4}\right)_{2}$ \\
\hline Y & Brushite & $7.62(001), 3.06 \mathrm{~A}(003)$ & $\mathrm{CaHPO}_{4} 2 \mathrm{H}_{2} \mathrm{O}$ \\
\hline
\end{tabular}

been formed by several flaky particles stacked together in the form of agglomerates (Panda et al. 2010). The change in morphology can be evidenced from sulfuric acid contaminated soil, which refers to anhydrite and bassanite mineral formations (Figure 9). Formation of well-bonded aggregation with small particle size can be evidenced in kaolin clay contaminated with phosphoric acid. Phosphogypsum treated clay contaminated with acids shows dense clay matrix with crystal formations rather detached particles much similarly to phosphoric acid treated clay. These changes in microstructure are clearly indicating the effect of acid contamination and phosphogypsum treatment on clay mineral behavior.

\subsection{Volume change behavior of kaolin clay}

Figure 10 shows the time-swelling curves of kaolin clay and its phosphogypsum treated counterpart on inundation with water and acid solutions under a seating load of $5 \mathrm{kPa}$. The curves depict that the kaolin clay inundated with water exhibited almost negligible swelling. The small number of exchangeable cations present at the edges of sheets of the kaolinite structure does not allow the clay to swell (Foster 1954). Further, the kaolin clay also exhibited a similar trend of increase in swelling as the duration of acid contamination increases in comparison with black cotton soil. Upon contamination with sulfuric acid and phosphoric acid, kaolin clay exhibited an equilibrium swelling of about $18 \%$ and $13 \%$, respectively. This increase in swelling during acid contamination is attributed to anion adsorption i.e., fast ligand replacement of hydroxyl ion by either sulphate ion or phosphate ion (Laiti et al. 1996; Eisazadeh et al. 2011) and formation of flocculated fabric. The size of the sulphate ion or phosphate ion being larger than the hydroxyl ion, each particle becomes bigger on replacement. The charge on the edges of kaolin clay particles will become increasingly positive in acidic environment due to the adsorption of hydrogen ions $\left(\mathrm{H}^{+}\right)$ resulting in flocculated, face-to-edge (F-E) structures (Olphen 1991; Gratchev, Towhata 2016). Kaolin clay exhibited higher compressibility to external load increments upon acid contamination (Figure 11). The compression index is also supporting the increase in deformation (Table 8). It is interesting to note that Gratchev, Towhata (2016) reported similar trends of increase in compressibilities of kaolinitic

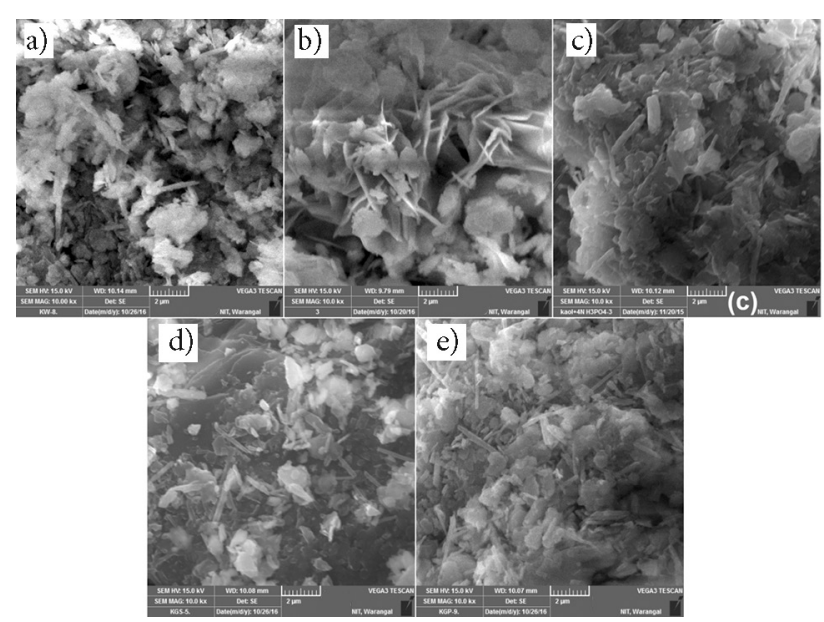

Figure 9. SEM images of kaolin clay (a) KW (b) KS (c) KP (d) KGS (e) KGP

soils due to long term sulfuric acid contamination. As stated earlier, it can be expected that the effect of mineralogical changes would be more significant on the volume change behavior of kaolin clay than the effect of anion adsorption as the complete mineral structure is failed during acid contamination. It can be seen from XRD results, that (i) the dissolution of minerals (calcite and ankerite) and formation of bassanite and anhydrite in sulfuric acid and (ii) formation of sarcopside (metal phosphate) in phosphoric acid, contributed to the volume changes observed in kaolin clay due to acid contamination. From Figure 10, it can be seen that the swelling at seating load is reduced for the treated soil as compared to that of untreated soil. The phosphogypsum treated kaolin clay exhibited an equilibrium swelling of about $12 \%$ and $7 \%$ with sulfuric acid and phosphoric acid, respectively. The swelling characteristics of kaolin clay were significantly affected by phosphogypsum treatment. However, the compressibility of treated clay was almost slightly lower than that of untreated clay in the case of sulfuric acid. Whereas, with phosphoric acid a greater reduction in compressibility was noted in treated clay. The resistance to new mineral formations such as sarcopside lead to reduction in swelling in both clays. Significant reduction in swelling and compressibility in phosphogypsum treated clays with phosphoric acid is attributed partially to the replacement of some amount of 
clay with phosphogypsum and mainly to the restriction of high volume mineral formation such as merlinoite and sarcopside.

Overall, it is concluded that the phosphogypsum treatment was found to be effective in the case of phosphoric acid as significant volume stability is obtained after treatment and ineffective in the case of sulfuric acid as the reduction in swelling and compressibility is low even after treatment. Thus, utilization of phosphogypsum not only

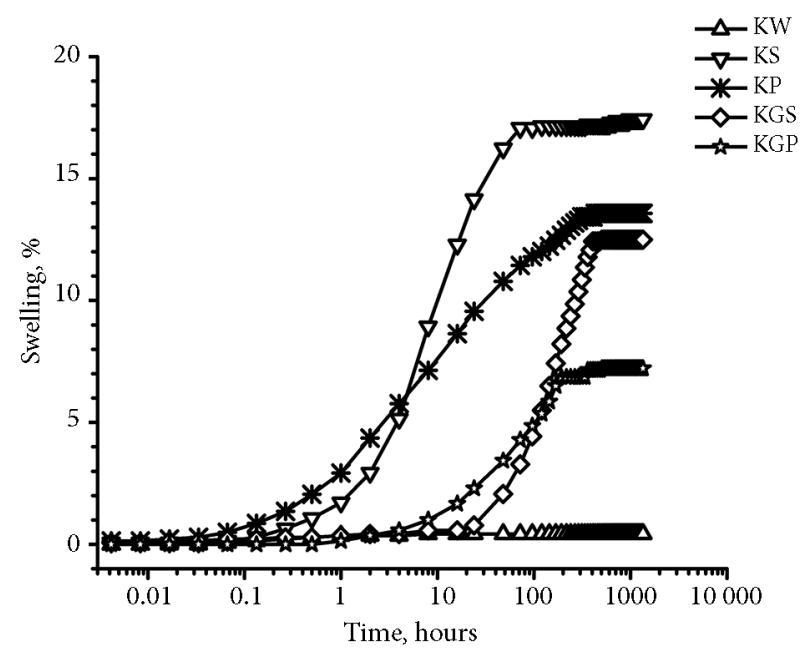

Figure 10. Time- swelling curves of kaolin clay

Table 8. Compression index of kaolin clay

\begin{tabular}{|c|c|}
\hline Soil & Compression index, $\mathrm{C}_{\mathrm{c}}$ \\
\hline KW & 0.18 \\
\hline KS & 0.35 \\
\hline KP & 0.26 \\
\hline KGS & 0.27 \\
\hline KGP & 0.10 \\
\hline
\end{tabular}

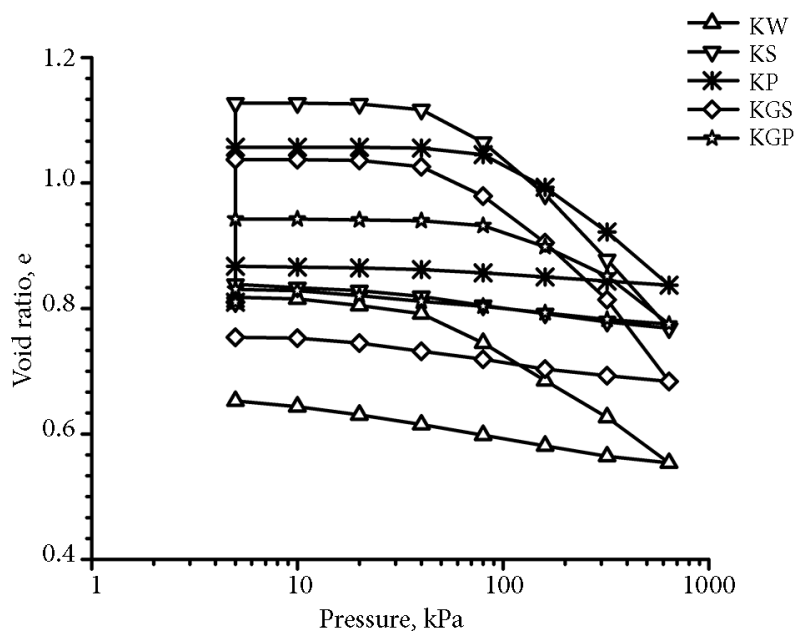

Figure 11. Compressibility behavior of kaolin clay provides solution to control phosphoric acid induced volume changes but also prevents the disposal, environmental and health problems.

\section{Conclusions}

Following are the conclusions brought out from the experimental results obtained in this study:

High equilibrium swelling and lesser compressibility of black cotton soil caused by $\mathrm{H}_{2} \mathrm{SO}_{4}$ and $\mathrm{H}_{3} \mathrm{PO}_{4}$ contamination is due to (a) replacement of $\mathrm{Ca}^{++}$by $\mathrm{H}^{+}$ions, (b) formation of flocculant fabric, and (c) mineral dissolution and neogenic formations such as alunogen and merlinoite.

The volume changes of $\mathrm{H}_{2} \mathrm{SO}_{4}$ and $\mathrm{H}_{3} \mathrm{PO}_{4}$ contaminated kaolin clay are due to (a) anion adsorption, (b) formation of flocculant, face-to-edge structures, and (c) dissolution of calcite and ankerite minerals and formation of sulphate and phosphate minerals.

The ill effects of phosphoric acid contamination on volume change behavior of clayey soils are effectively controlled by phosphogypsum treatment. However, more studies are required to control the ill effects of sulfuric acid contamination.

\section{Funding}

This research was financially supported by Department of Science and Technology (DST), Science and Engineering Research Board (SERB), India, under Fast Track Scheme for Young Scientist [grant number SB/FTP/ETA412/2012].

\section{References}

Al-Khailany, B. M.; Al-Omari, R. R.; Sagman, W. F. 2008. Geological alterations and chemical treatment of a polluted limestone foundation, in International Conference on Case Histories in Geotechnical Engineering, 11-16 August 2008, Arlington, VA.

Al-Omari, R. R.; Mohammed, W. K.; Nashaat, I. H.; Kaseer, O. M. 2007. Effect of sulfuric and phosphoric acids on the behavior of a limestone foundation, Indian Geotechnical Journal 37: 263-282.

Assa'ad, A. 1998. Differential upheaval of phosphoric acid storage tanks in Aqaba, Jordan, Journal of Performance of Constructed Facilities 12: 71-76.

https://doi.org/10.1061/(ASCE)0887-3828(1998)12:2(71)

Azam, S. 2003. Influence of mineralogy on swelling and consolidation of soils in eastern Saudi Arabia, Canadian Geotechnical Journal Journal 40(5): 964-975. https://doi.org/10.1139/t03-047

Brundavanam, S.; Poinern, G. E. J.; Fawcett, D. 2014. Growth of flower-like brushite structures on magnesium substrates and their subsequent low temperature transformation to hydroxyapatite, American Journal of Biomedical Engineering 4(4): 79-87.

Chunikhin,V. G.; Mavrodi, V. Kh.; Kramarenko, O. A.; Dobromil'skaya, N. G. 1988. Effect of leakage of industrial alkali solutions on the construction properties of soils, Soil Mechanics and Foundation Engineering 25(6): 559-561. https://doi.org/10.1007/BF01721619 
Cokca, E.; Birand, A. 1993. Determination of cation exchange capacity of clayey soils by the methylene blue test, Geotechnical Testing Journal 16(4): 518-524.

https://doi.org/10.1520/GTJ10291J

CPCB 2012. Guidelines for management and handling of phosphogypsum generated from phosphoric acid plants (Final Draft), Central Pollution Control Bord, New Delhi, India.

De Rezende, L. R.; Curado, T. D. S.; Silva, M. V.; Mascarenha, M. M. D. A.; Metogo, D. A. N.; Neto, M. P. C.; Bernucci, L. L. B. 2016. Laboratory study of phosphogypsum, stabilizers, and tropical soil mixtures, Journal of Materials in Civil Engineering, p. 04016188.

Degirmenci, N.; Okucu, A.; Turabi, A. 2007. Application of phosphogypsum in soil stabilization, Building and Environment 42(9): 3393-3398.

https://doi.org/10.1016/j.buildenv.2006.08.010

Eisazadeh, A.; Kassim, K. A.; Nur, H. 2011. Characterization of phosphoric acid-and lime-stabilized tropical lateritic clay, Environmental Earth Sciences Sciences 63(5): 1057-1066.

Foster, M. D. 1954. The relation between composition and swelling in clays, Clays and Clay Minerals 3: 205-220. https://doi.org/10.1346/CCMN.1954.0030117

Gates, W. P.; Anderson, J. S.; Raven, M. D.; Churchman, G. J. 2002. Mineralogy of a bentonite from Miles, Queensland, Australia and characterisation of its acid activation products, Applied Clay Science 20: 189-97.

https://doi.org/10.1016/S0169-1317(01)00072-2

Ghafoori, N.; Chang, W. F. 1993. Investigation of phosphate mining waste for construction materials, Journal of Materials in Civil Engineering Engineering 5(2): 249-264.

https://doi.org/10.1061/(ASCE)0899-1561(1993)5:2(249)

Grant, R.; Christian, J. T.; Vanmarcke, E. H. 1974. Differential settlement of buildings, Journal of Geotechnical Division 100: 973-991.

Gratchev, I.; Towhata, I. 2011. Compressibility of natural soils subjected to long-term acidic contamination, Environmental Earth Sciences 64: 193-200. https://doi.org/10.1007/s12665-010-0838-2

Gratchev, I.; Towhata, I. 2016. Compressibility of soils containing kaolinite in acidic environments, KSCE Journal of Civil Engineering Engineering 20(2): 623-630. https://doi.org/10.1007/s12205-015-0141-6

Grim, R. E. 1953. Clay Mineralogy. McGraw-Hill, Inc., New York.

IS (Indian Standard). 1970. Classification and identification of soils for general engineering purposes. Bureau of Indian Standards 1498. India, New Delhi.

IS (Indian Standard). 1980. Determination of specific gravity/section 1 fine grained soils. Bureau of Indian Standards 2720 (Part 3). India, New Delhi.

IS (Indian Standard). 1980. Determination of water content-dry density relation using light compaction. Bureau of Indian Standards 2720 (Part 7). India, New Delhi.

IS (Indian Standard). 1985. Determination of grain size analysis of soils. Bureau of Indian Standards 2720 (Part 4). India, New Delhi.

IS (Indian Standard). 1985. Determination of Liquid and Plastic Limit. Bureau of Indian Standards 2720 (Part 5). India, New Delhi.

IS (Indian Standard). 1986. Determination of consolidation properties. Bureau of Indian Standards 2720 (Part 15). India, New Delhi.

Isaev, B. N.; Tsapkova, N. N.; Badeev, S. Yu.; Balatskii, V. B. 1995. Protecting the bed soils of foundations from damaging wetting by acids, Soil Mechanics and Foundation Engineering 32: $130-134$

https://doi.org/10.1007/BF02336274
Izbash, Yu. V.; Mishurova, T. V.; Bronzhaev, M. F. 1989. Correction of consequences of harmful soaking of acid base of "Khimprom" design division shop in Slavyansk, Soil Mechanics and Foundation Engineering 26: 94-97. https://doi.org/10.1007/BF02302816

James, J.; Pandian, P. K. 2014. Effect of phosphogypsum on strength of lime stabilized expansive soil, Gradevinar 66(12): 1109-1116.

Jha, A. K.; Sivapullaiah, P. V. 2014. Role of gypsum on microstructure and strength of soil, Environmental Geotechnics Geotechnics 3(2): 78-89.

https://doi.org/10.1680/envgeo.13.00084

Joshi, R. C.; Pan, X.; Lohita, P. 1994. Volume change in calcareous soils due to phosphoric acid contamination, in Proceedings of $13^{\text {th }}$ International Conference on SM and FE, 5-10 January 1994, New Delhi, India.

Komadel, P. 2003. Chemically modified smectites, Clay Minerals 38: $127-138$.

https://doi.org/10.1180/0009855033810083

Komadel, P. 2016. Acid activated clays: Materials in continuous demand, Applied Clay Science 131: 84-99. https://doi.org/10.1016/j.clay.2016.05.001

Kumar, S.; Dutta, R. K.; Mohanty, B. 2014. Engineering properties of bentonite stabilized with lime and phosphogypsum, Slovak Journal of Civil Engineering 22(4): 35-44. https://doi.org/10.2478/sjce-2014-0021

Kumar, S.; Dutta, R. K.; Mohanty, B. 2015. Potential of bentonitelime-mix modified with phosphogypsum and reinforced with sisal fibres, Periodica Polytechnica. Civil Engineering Engineering 59(2): 143-154.

Laiti, E.; Persson, P.; Oehman, L. O. 1996. Surface complexation andprecipitation at the $\mathrm{H}^{+}$-orthophosphate-aged c- $\mathrm{Al}_{2} \mathrm{O}_{3}$ /waterinterface, Langmuir 12: 2969-2975. https://doi.org/10.1021/la9515074

Latifi, N.; Meehan, C. L.; Majid, M. Z. A.; Horpibulsuk, S. 2016. Strengthening montmorillonitic and kaolinitic clays using a calcium-based non-traditional additive: A micro-level study, Applied Clay Science 132-133: 182-193.

https://doi.org/10.1016/j.clay.2016.06.004

Li, L.; Stanforth, R. 2000. Distinguishing adsorption and surface precipitation of phosphate on goethite ( $\alpha-\mathrm{FeOOH})$, Journal of colloid and interface science science 230(1): 12-21.

Lukas, R. G.; Gnaedinger, Jr. R. J. 1972. Settlement due to chemical attack of soils, in Proc. ASCE Special Conference on the Performance of Earth and Earth-Supported Structures, 11-14 June 1972, Purdue University, Lafayette, Indiana.

Madejova, J.; Bujdak, J.; Janek, M.; Komadel, P. 1998. Comparative FT-IR study of structural modifications during acid treatment of dioctahedral smectites and hectorite, Spectrochim Acta A 54: 1397-1406. https://doi.org/10.1016/S1386-1425(98)00040-7

Madejova, J.; Komadel, P. 2001. Baseline studies of the clay minerals society source clays: infrared methods, Clays and Clay Minerals 49(5): 410-432.

https://doi.org/10.1346/CCMN.2001.0490508

Mal'tsev, A. V. 1998. Theoretical and experimental investigations of the effect of aggressive wetting on various types of bed soils, Soil Mechanics and Foundation Engineering 35: 83-86. https://doi.org/10.1007/BF02465914

Ming, D. W.; Boettinger, J. L. 2001. Zeolites in soil environments, Reviews in Mineralogy and Geochemistry Geochemistry 45(1): 323-345. https://doi.org/10.2138/rmg.2001.45.11 
Mitchell, J. K. 1993. Fundamentals of Soil Behavior. $2^{\text {nd }}$ ed. John Wiley \& Sons.

Olphen, H. V. 1991. An introduction to clay colloid chemistry. Krieger Publishing Company.

Onal, M. 2007. Swelling and cation exchange capacity relationship for the samples obtained from a bentonite by acid activation and heat treatments, Applied Clay Science 37: 74-80. https://doi.org/10.1016/j.clay.2006.12.004

Pakhomova, A. S.; Armbruster, T.; Krivovichev, S. V.; Yakovenchuk, V. N. 2014. Dehydration of the zeolite merlinoite from the Khibiny massif, Russia: an in situ temperature-dependent single-crystal X-ray study, European Journal of Mineralogy Mineralogy 26(3): 371-380. https://doi.org/10.1127/0935-1221/2014/0026-2380

Panda, A. K.; Mishra, B. G.; Mishra, D. K.; Singh, R. K. 2010. Effect of sulfuric acid treatment on the physico-chemical characteristics of kaolin clay, Colloids and Surfaces A: Physicochemical and Engineering Aspects 363: 98-104. https://doi.org/10.1016/j.colsurfa.2010.04.022

PCPDFWIN. 1999. The powder diffraction file, joint committee for powder diffraction studies (JCPDS). International Centre for Diffraction Data (ICDD), Newtown Square, PA, USA.

Rao, S. M.; Rao, K. S. S. 1994. Ground heaving from caustic soda solution spillage - A case study, Soils and Foundations 34(2): 13-18. https://doi.org/10.3208/sandf1972.34.2_13

Rao, S. M.; Reddy, P. M. R. 1997. Laboratory studies on the volume change characteristics of kaolinite contaminated with sodium phosphate/sulphate, Geotechnical Testing Journal 20(3): 362-367. https://doi.org/10.1520/GTJ19970012

Ross, S. 1989. Soil processes. Routledge, London.

Shekhtman, L. M.; Baranov, V. T.; Nesterenko, G. F. 1995. Building deformations caused by the leakage of chemical reagents, Soil Mechanics and Foundation Engineering 32: 32-36. https://doi.org/10.1007/BF02336250

Shen, W.; Zhou, M.; Zhao, Q. 2007. Study on lime-flyash-phosphogypsum binder, Construction and Building Materials Materials 21(7): 1480-1485.

https://doi.org/10.1016/j.conbuildmat.2006.07.010

Sheng, H. L.; Mu, C. L. 1998. Recovery of sulfuric acid from waste aluminum surface processing solution by diffusion dialysis, Journal of Hazardous Materials 60: 247-257. https://doi.org/10.1016/S0304-3894(98)00099-5

Sibley, M. H.; Vadgama, N. J. 1986. Investigation of ground heave at ICI Mond Division, Castner-Keller works, Runcorn. Geological Society, London, Engineering Geology Special Publications 2: 367-373.

Sivapullaiah, P. V. 2015. Surprising Soil Behavior: Is It Really!!!, Indian Geotechnical Journal 45(1): 1-24. https://doi.org/10.1007/s40098-014-0141-3
Sivapullaiah, P. V.; Allam, M. M.; Sankara, G. 2004. Structural distortion due to heaving of foundation soil induced by alkali contamination, in Proc. International Conference on Structural and Foundation Failures, 2-4 August 2004, Singapore.

Sivapullaiah, P. V.; Prasad, B. G.; Allam, M. M. 2009. Effect of sulfuric acid on swelling behavior of an expansive soil, Soil and Sediment Contamination 18: 121-135. https://doi.org/10.1080/15320380802660289

Sokolovich, V. E. 1995. Chemical heaving of soils, Soil Mechanics and Foundation Engineering. 32: 135-137. https://doi.org/10.1007/BF02336275

Sokolovich, V. E.; Troitskii, G. M.; 1976. Heaving of a sand base as a consequence of the development of secondary crystal hydrate formations, Soil Mechanics and Foundation Engineering 13(6): 376-378. https://doi.org/10.1007/BF01706704

Sridharan, A.; Nagaraj, T. S.; Sivapullaiah, P. V. 1981. Heaving of soil due to acid contamination, in Proceedings of the $10^{\text {th }}$ International Conference on Soil Mechanics and Foundation Engineering, 15-19 June 1981, Stockholm, Sweden.

Stephenson, R. W.; Dempsey, B. A.; Heagler, J. B. 1989. Chemically induced foundation heave. Foundation Engineering Current Principles and Practice, ASCE, Geotechnical Engineering Div. New York, 1633-1642.

Steudel, A.; Batenburg, L. F.; Fischer, H. R.; Weidler, P. G.; Emmerich, K. 2009. Alteration of swelling clay minerals by acid activation, Applied Clay Science 44(1-2): 105-115. https://doi.org/10.1016/j.clay.2009.02.002

Tyagi, B.; Chudasama, C. D.; Jasra, R. V. 2006. Determination of structural modification in acid activated montmorillonite clay by FT-IR spectroscopy, Spectrochimica Acta Part A 64: 273-278. https://doi.org/10.1016/j.saa.2005.07.018

Vicente-Rodriguez, M. A.; Suarez, M.; Banares-Munoz, M. A.; Lopez-Gonzalez, J. D. 1996. Comparative FT-IR study of the removal and structural modifications during acid silicates of octahedral cations treatment of several silicates, Spectrochim Acta Part A 52: 1685-1694. https://doi.org/10.1016/S0584-8539(96)01771-0

Vronskii, A. V.; Boldyrev, G. G.; Terent'ev, B. I. 1978. Deformations of buildings and structures of the Balakovo chemical plant being constructed on swelling soils, Soil Mechanics and Foundation Engineering 15: 290-293. https://doi.org/10.1007/BF02110447

Zhang, A. B.; Pan, L.; Zhang, H. Y.; Liu, S. T.; Ye, Y.; Xia, M. S.; Chen, X. G. 2012. Effects of acid treatment on the physicochemical and pore characteristics of halloysite, Colloids and Surfaces A: Physicochemical and Engineering Aspects 396: 182-188.

https://doi.org/10.1016/j.colsurfa.2011.12.067 